\title{
Gas Exchanges and Stem Water Potential Define Stress Thresholds for Efficient Irrigation Management in Olive (Olea europea L.)
}

\author{
Giulia Marino ${ }^{1,2, *}$, Tiziano Caruso ${ }^{2}$, Louise Ferguson ${ }^{3}$ (DD and Francesco Paolo Marra $^{2}$ (D) \\ 1 Department of Land Air and Water Resources, 213, Veihmeyer Hall, University California Davis, \\ One Shields Ave., Davis, CA 95616, USA \\ 2 Dipartimento Scienze Agrarie, Alimentari e Forestali, Università di Palermo, Viale delle Scienze Edificio 4 \\ Ingresso H, 90128 Palermo, Italy; tiziano.caruso@unipa.it (T.C.); francescopaolo.marra@unipa.it (F.P.M.) \\ 3 Department of Plant Sciences, Wickson Hall, University of California Davis, One Shields Avenue, Davis, \\ CA 95616, USA; lferguson@ucdavis.edu \\ * Correspondence: giumarino@ucdavis.edu; Tel.: +1-530-304-4509
}

Received: 4 February 2018; Accepted: 15 March 2018; Published: 20 March 2018

\begin{abstract}
With climate change and decreased water supplies, interest in irrigation scheduling based on plant water status is increasing. Stem water potential ( $\left.\Psi_{\text {SWP }}\right)$ thresholds for irrigation scheduling in olive have been proposed, however, a physiologically-based evaluation of their reliability is needed. A large dataset collected at variable environmental conditions, growing systems, and genotypes was used to characterize the relation between $\Psi_{\text {SWP }}$ and gas exchanges for olive. Based on the effect of drought stress on the ecophysiological parameters monitored, we described three levels of stress: no stress ( $\Psi_{\text {SWP }}$ above about $-2 \mathrm{MPa}$ ), where the high variability of stomatal conductance $\left(g_{s}\right)$ suggests a tight stomatal control of water loss that limit $\Psi_{S W P}$ drop, irrigation volumes applied to overcome this threshold had no effect on assimilation but reduced intrinsic water use efficiency (iWUE); moderate-stress ( $\Psi_{\text {SWP }}$ between about -2.0 and $-3.5 \mathrm{MPa}$ ), where iWUE can be increased without damage to the photosynthetic apparatus of leaves; and high-stress ( $\Psi_{\mathrm{SWP}}$ below about $-3.5 \mathrm{MPa}$ ), where $\mathrm{g}_{\mathrm{s}}$ dropped below $150 \mathrm{mmol} \mathrm{m}^{-2} \mathrm{~s}^{-1}$ and the intercellular $\mathrm{CO}_{2}$ concentration increased proportionally, suggesting non-stomatal limitation to photosynthesis was operative. This study confirmed that olive $\Psi_{\text {SWP }}$ should be maintained between -2 and $-3.5 \mathrm{MPa}$ for optimal irrigation efficiency and to avoid harmful water stress levels.
\end{abstract}

Keywords: assimilation; stomatal conductance; photosynthesis; water status; water use efficiency

\section{Introduction}

Olive (Olea europaea L.) is a drought resistant crop traditionally grown under rainfed condition in low density plantation. Recently, with the introduction of the super-high-density (SHD) system, characterized by very high planting density (1600-2000 trees per ha) and trees trained as hedgerows, olive orchard management has changed deeply. SHD orchards offer many advantages: they reach productivity very few years after planting, allow mechanization of harvesting and partial mechanization of pruning (tree topping) and a significant reduction in production costs [1-3]. However, increased planting density increases light interception [4], root competition [5], and plant sensitivity to drought [6]. This suggests irrigation parameters may also need to change. Irrigation is generally based on orchard water use (e.g., crop evapotranspiration, ETc), but multiple studies have demonstrated this method, because it does not consider plant water status, may overestimate the irrigation required for optimal yield [7-9] and reduce orchard water use efficiency. 
More efficient, plant-based irrigation scheduling would be of great benefit as climate change advances and water supplies dwindle $[10,11]$. Plant-based irrigation methods recognize the tree as the best indicator of its water status, and allow growers tailoring water applications to actual tree's needs and status, thus potentially reducing the non-beneficial water uses and ensuring a precise stress control.

Among the current water status measurements available, stem water potential ( $\left.\Psi_{\text {SWP }}\right)$ measured at midday, is the most reliable, and most widely studied [7,12-15]. It is used as reference of water status to calibrate new methodologies, define waters stress levels and manage deficit irrigation methodologies. However, the reported values of $\Psi_{\text {SWP }}$ are not consistent. This lack of consistent results is probably a function of environmental variability among orchards, primarily evaporative demand [16] and the different drought resistance mechanisms of the different olive genotypes [6,17].

When stomatal conductance is used as stress indicator common pattern on the response of photosynthesis to stress intensity are found [16].

Three stages of photosynthesis inhibition as a function of water stress intensity are reported [18-21].

Under mild-to-moderate drought-stress, a parallel decline in $A_{n}$ and $g_{s}$ is observed [12]. In this first stage stomata close to prevent water loss, reducing stomatal conductance $\left(g_{s}\right)$, photosynthetic rate $\left(A_{n}\right)[22,23]$, and shoot growth and fruit production [24]. Therefore, intrinsic water use efficiency (iWUE) increases with stress.

More severe water deficits (stage II and III) strongly and directly affect net photosynthesis [18,25-28] and the tree's ability to recover from stress $[29,30]$.

In stage II $C_{i}$ and $g_{s}$ are directly correlated showing that stomatal limitation are still predominant while in stage III $C_{i}$ increases as stomata close suggesting metabolic impairments to the photosynthetic system are predominant. In this last stage, iWUE decreases.

Collectively, the results demonstrate that a physiological characterization of stress levels is needed for a more sensitive plant based deficit irrigation scheduling, with the objective of increasing WUE while maintaining yield.

In this study, we aim to characterize the relationship between midday stem water potential and gas exchange for olive at variable crop conditions. We used a large dataset from two different experiments carried out in recent years [7,17].

The variability of environmental conditions (two different locations in two different years), genotypes ('Arbequina', 'Nocellara del Belice', and 'Olivo di Mandanici') and planting design and tree density (super high density, high density, and low density) provide sufficient wide dataset to smooth out variability in physiological behavior generally associated to difference in experimental conditions [31].

The different mechanisms involved in stomatal and non-stomatal control of photosynthesis at the different stress levels are investigated and used to define $\Psi_{S W P}$ thresholds for irrigation of olive orchards that satisfy good physiologically-based criteria for a sustainable and efficient irrigation management.

Overall aim was to provide practical recommendation to improve irrigation management and avoid harmful stress while maintaining orchard productivity.

\section{Materials and Methods}

Data were collected during two different experiments. The first experiment was carried out in 2009 season in the same SHD orchard (cultivar 'Arbequina', 1905 trees/ha) where Marra et al. [7] made their experiment.

The orchard was planted in 2004 on a private farm located in Southern Italy $\left(37^{\circ} 48^{\prime} 0^{\prime \prime} \mathrm{N}, 12^{\circ} 26^{\prime} 0^{\prime \prime} \mathrm{E}\right.$, $12 \mathrm{~m}$ altitude). The climate of the area and the experimental soil have been described in Marra et al. [7].

Five different irrigation treatments were imposed, corresponding to $16 \%, 21 \%, 41 \%, 62 \%$ and $83 \%$ of Crop Water Requirement (CWR). The FAO CROPWAT model for deficit irrigation scheduling was used to calculate CWR starting from the ETc and rain data. 
ETc was established a priori using FAO procedure published as FAO Irrigation and Drainage Paper No. 56 [32]. In particular, ETc was calculated as ETc $=$ ETo $\times \mathrm{Kc} \times \mathrm{Kr}$, where ETo (30-year average reference evapotranspiration) was estimated using the Penman-Monteith equation and environmental data provided by a public weather station (SIAS, Servizio Informativo Agrometeorologico Siciliano), located in the proximity of the orchard; $\mathrm{Kc}$ is crop coefficient obtained from literature [32-36] and varied from 0.50 to 0.75 , depending on the phenology of the trees; $\mathrm{Kr}$ is a coefficient related to the percentage of ground covered by the crop and resulted 0.58 based on measurements of canopy volume and subsequent calculations of the percentage of ground area coverage $(42 \%)$.

Details on the irrigation system and orchard practices were also given in Marra et al. [7].

A randomized block design was used with 5 blocks of 45 trees each ( 9 trees per treatment), distributed between three adjacent rows; within each block one tree per irrigation treatment was randomly selected in the central row and subsequently monitored. Stem water potential ( $\left.\Psi_{S W P}\right)$ and gas exchanges were measured on the 11 August, when the trees are more resistant to drought, and 1 September, when the trees are sensitive to drought [37].

The second experiment was carried out in 2014, in two adjoining olive orchards located near Sciacca $\left(37^{\prime} 32^{\prime \prime} \mathrm{N}, 150 \mathrm{~m}\right.$ above sea level) in southwest Sicily (Italy), the same area where Marino et al. [15] conducted their experiment. A more detailed description of the climate and the soil is reported in Marino et al. [6].

Out of the two adjoining orchards, one was a traditional 10-year-old widely spaced (200 trees/ha) orchard (cv. 'Nocellara del Belice'). Trees were trained as vase shape and rain-fed all over the season.

The adjoining orchard was a hedgerow trained high density (HD, 1000 trees/ha) 3-year-old orchard. Two genotypes ('Nocellara del Belice' and 'Olivo di Mandanici'), characterized by different vigor and productive potential [38] were monitored for their response to short term water deficit. The irrigation was supplied from June, every 7-10 days. At the beginning of July, irrigation was stopped for a number of days until the midday $\Psi_{\text {SWP }}$ decreased below $-2.5 \mathrm{MPa}[7,26]$. A re-watering period followed. Detail about orchard characteristics, experimental design and irrigation management are reported in Marino et al. [6]. Stem water potential and gas exchange were monitored every 10 days, from June until October.

Stem water potential was measured at midday using a pressure chamber (PMS Instrument Co., Corovallis, OR, USA). Fully-exposed shoots of the current growth season with five or six expanded leaves were covered with plastic envelopes and aluminum reflective foil at least $1 \mathrm{~h}$ before measurement in order to reduce leaf transpiration [39] and equilibrate stem water potential with branch water potential. On the same days when the $\Psi_{\text {SWP }}$ was measured, we conducted a series of leaf gas exchange measurements on fully expanded leaves, using a CIRAS-2 (PP system ${ }^{\circledR}$ ) portable gas exchange system $\left(\mathrm{CO}_{2}\right.$ and $\left.\mathrm{H}_{2} \mathrm{O}\right)$ connected to a gas exchange chamber (Parkinson Leaf Cuvette). The system measured principal eco-physiological parameters, such as light-saturated net $\mathrm{CO}_{2}$ assimilation $\left(\mathrm{A}_{\mathrm{n}}, \mu \mathrm{mol} \mathrm{m} \mathrm{m}^{-2} \mathrm{~s}^{-1}\right)$, stomatal conductance $\left(\mathrm{g}_{\mathrm{s}}, \mathrm{mmol} \mathrm{m}^{-2} \mathrm{~s}^{-1}\right)$, atmospheric pressure, air and leaf temperature, and air $\mathrm{CO}_{2}$ and intercellular $\mathrm{CO}_{2}$ concentration $\left(\mathrm{C}_{\mathrm{i}}\right)$ [40,41]. Intrinsic water use efficiency (iWUE, $\mathrm{mmol} \mathrm{mol}^{-1}$ ) was calculated as the relationship between $A_{n}$ and $g_{s}$.

A commercial software package (TableCurve 2D; SYSTAT Software Inc., Chicago, IL, USA) was used to find the best-fit and the function parameters of the relationship between the principal eco-physiological variables.

Statistical analysis of the data (GLM) was carried out using the Systat (SYSTAT Software Inc., Chicago, IL, USA); significance was set at $p \leq 0.05$.

\section{Results}

As shown in Figure 1, $A_{n}$ and $g_{s}$ were well correlated with midday $\Psi_{S W P}\left(r^{2}\right.$ of 0.61 and 0.51 , respectively). 


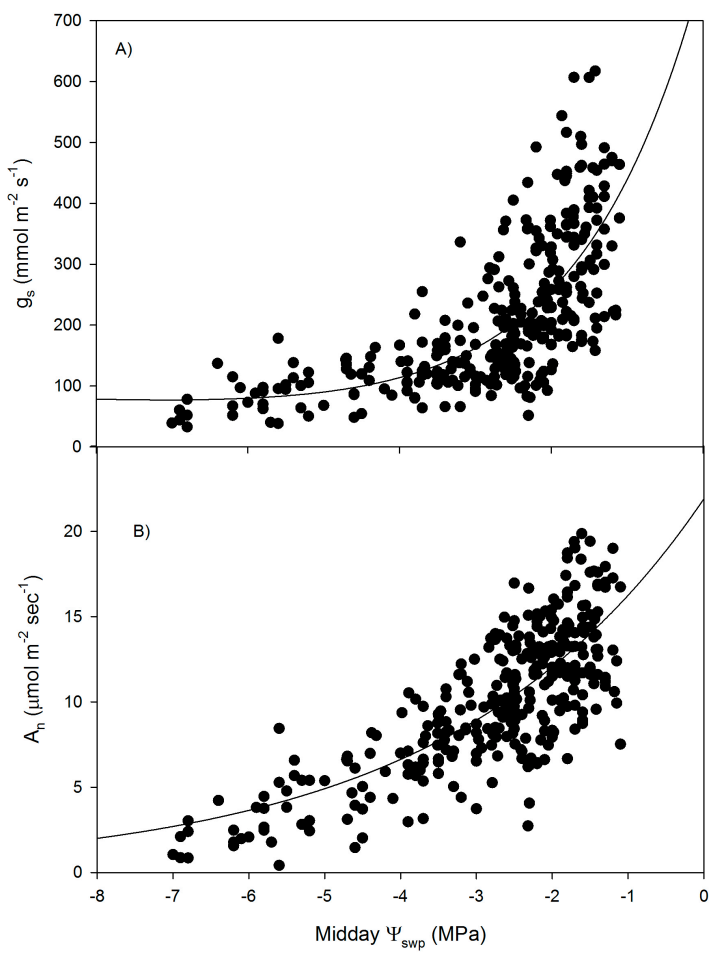

Figure 1. Relationship between (A) stomatal conductance $\left(\mathrm{g}_{\mathrm{s}}, \mathrm{mmol} \mathrm{m} \mathrm{m}^{-2} \mathrm{~s}^{-1}\right)$ and (B) net photosynthesis $\left(A_{n}, \mu \mathrm{mol} \mathrm{m}{ }^{-2} \mathrm{~s}^{-1}\right)$ relative to the stem water potential ( $\left.\Psi_{\mathrm{SWP}}, \mathrm{MPa}\right)$ measured at midday. The best fit relationship for the entire $g_{s}$ data pool was performed using a double exponential function: $y=39 \times \mathrm{e}^{(-0.08 x)}+744 \times \mathrm{e}^{(0.63 x)} ; \mathrm{r}^{2}=0.51: p<0.0001$; the best fit relationship for the entire $\mathrm{A}_{\mathrm{n}}$ data pool was performed using a double exponential function: $y=3.1 \times \mathrm{e}^{(0.29 x)}+18.9 \times \mathrm{e}^{(0.30 x)}$; $\mathrm{r}^{2}=0.61, p<0.0001$.

The $\Psi_{\text {SWP }}$ ranged from minimum values of $-7 \mathrm{MPa}$ to maximum values of $-1 \mathrm{MPa}$. $\mathrm{g}_{\mathrm{s}}$ ranged from $30 \mathrm{mmol} \mathrm{m}^{-2} \mathrm{~s}^{-1}$ at $\Psi_{\mathrm{SWP}}$ lower than $-6 \mathrm{MPa}$ up to $600 \mathrm{mmol} \mathrm{m}^{-2} \mathrm{~s}^{-1}$ at $\Psi_{\mathrm{SWP}}$ higher than $-2 \mathrm{MPa}$; for the same $\Psi_{\text {SWP }}$ range, $\mathrm{A}_{\mathrm{n}}$ varied from maximum values of $20 \mu \mathrm{mol} \mathrm{m}{ }^{-2} \mathrm{~s}^{-1}$ to minimum values of $0.5 \mu \mathrm{mol} \mathrm{m}{ }^{-2} \mathrm{~s}^{-1}$.

Data were fitted against a double exponential function. The high variability of the response of $\mathrm{g}_{\mathrm{s}}$ and $\mathrm{A}_{\mathrm{n}}$ relative to $\Psi_{\mathrm{SWP}}$ at different degree of stress supports this approach of curve fitting and distinguished three regions of $\Psi_{\text {SWP }}$.

For $\Psi_{\text {SWP }}$ under the threshold of approximately $-3.5 \mathrm{MPa}$, gas exchange maintained relatively constant and low rates, and $\Psi_{\text {SWP }}$ slightly affected gas exchange. For instance, each unit increase in $\Psi_{\text {SWP }}$ increased $g_{\mathrm{s}}$ by $25 \mathrm{mmol} \mathrm{m}^{-2} \mathrm{~s}^{-1}$ (8\% of total $\mathrm{g}_{\mathrm{s}}$ increase) and $\mathrm{A}_{\mathrm{n}}$ of $1.7 \mu \mathrm{mol} \mathrm{m}^{-2} \mathrm{~s}^{-2}(12 \%$ of total $\mathrm{A}_{\mathrm{n}}$ increase).

When $\Psi_{\text {SWP }}$ increased, its relative influence on gas exchange was higher. One unit increase in $\Psi_{\text {SWP }}$ within the range of -3.5 to $-2 \mathrm{MPa}$ increased $\mathrm{g}_{\mathrm{s}}$ by $88 \mathrm{mmol} \mathrm{m}^{-2} \mathrm{~s}^{-1}$ ( $25 \%$ of total $\mathrm{g}_{\mathrm{s}}$ increase) and $A_{n}$ by $2.6 \mu \mathrm{mol} \mathrm{m}^{-2} \mathrm{~s}^{-2}$ (18\% total $\mathrm{A}_{\mathrm{n}}$ increase).

Above the threshold of $-2 \mathrm{MPa}$, for each unit increase in $\Psi_{\mathrm{SWP}}, \mathrm{g}_{\mathrm{s}}$ increased by $137 \mathrm{mmol} \mathrm{m}^{-2} \mathrm{~s}^{-1}$ ( $40 \%$ of total $g_{s}$ increase) while $A_{n}$ increased by 5 ( $35 \%$ of total $A_{n}$ increase). Higher dispersion of data points around the curve was observed at increasing $\Psi_{\mathrm{SWP}}$, suggesting the superimposition of other factor at low stress levels. This was particularly clear at $\Psi_{\text {SWP }}$ above $-2 \mathrm{MPa}$ where, for the same $\Psi_{\text {SWP }}$ value, $\mathrm{g}_{\mathrm{s}}$ varied from 98 to $547 \mathrm{mmol} \mathrm{m}^{-2} \mathrm{~s}^{-1}$.

Sub-stomatal $\mathrm{CO}_{2}$ concentration $\left(\mathrm{C}_{\mathrm{i}}\right)$ curvilinearly decreased, from approx. $250 \mu \mathrm{mol} \mathrm{mol}^{-1}$ to minimum values of $160 \mu \mathrm{mol} \mathrm{mol}^{-1}$, as $\mathrm{g}_{\mathrm{s}}$ decreased from 600 to $100 \mathrm{mmol} \mathrm{m}^{-2} \mathrm{~s}^{-1}$, a (Figure 2). For $\mathrm{g}_{\mathrm{s}}$ under the threshold of $150 \mathrm{mmol} \mathrm{m}^{-2} \mathrm{~s}^{-1}$ a deviation from the curve was observed and $\mathrm{C}_{\mathrm{i}}$ started to increase for a group of datapoints. These datapoints, characterized by $g_{s}$ lower than $150 \mathrm{mmol} \mathrm{m}^{-2} \mathrm{~s}^{-1}$ 
and $C_{i}$ higher than $220 \mu \mathrm{mol} \mathrm{mol}{ }^{-1}$ (average of all the data), were plotted separately and were all characterized by $\Psi_{\text {SwP }}$ lower than $-3.5 \mathrm{MPa}$.

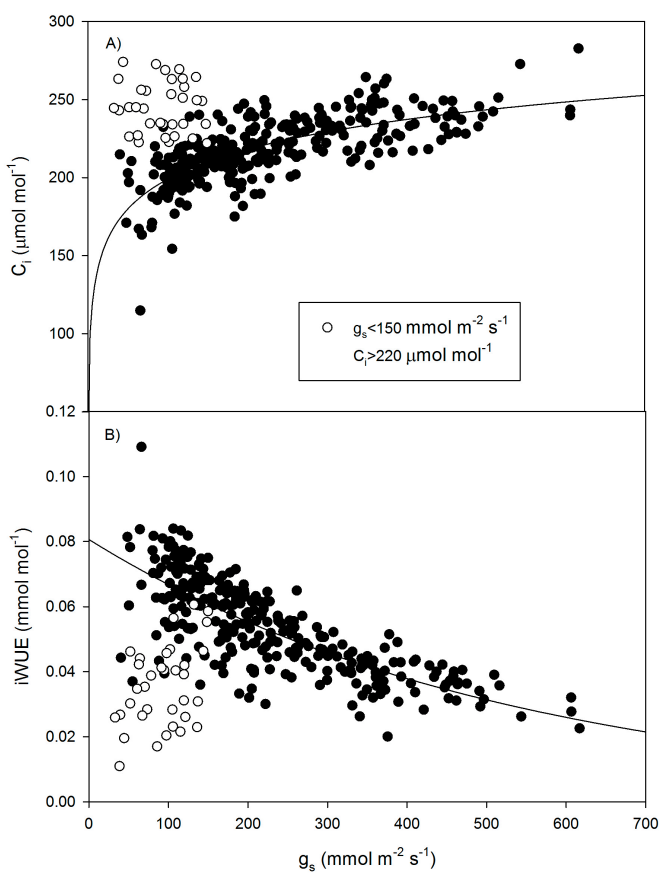

Figure 2. Relationship between (A) the sub stomatal $\mathrm{CO}_{2}$ concentration $\left(\mathrm{C}_{\mathrm{i}}, \mu \mathrm{mol} \mathrm{mol} \mathrm{m}^{-1}\right)$ and (B) intrinsic water use efficiency (iWUE, $\mathrm{mmol} \mathrm{mol}^{-1}$ ) relative to stomatal conductance $\left(\mathrm{g}_{\mathrm{s}}, \mathrm{mmol} \mathrm{m}^{-2} \mathrm{~s}^{-1}\right)$. Data characterized by $\mathrm{g}_{\mathrm{s}}<150 \mathrm{mmol} \mathrm{m}^{-2} \mathrm{~s}^{-1}$ and $\mathrm{C}_{\mathrm{i}}>220 \mu \mathrm{mol} \mathrm{mol}^{-1}$ (average of the population) were plotted separately. The best fit relationship for $C_{i}$ was performed using a logarithmic function: $y=71.8+26.7 \times \ln (\operatorname{abs}(x)) ; \mathrm{r}^{2}=0.52$. The best fit relationship for iWUE was performed using an exponential function: $y=0.80 \times \mathrm{e}^{(-0.019 x)} ; \mathrm{r}^{2}=0.58$.

The relation between $g_{s}$ and $A_{n}$ was positive and exponential (Figure 3). To better visualize the effect of the stress on stomatal control of photosynthesis, we separately plotted data in three groups based on the analysis of the previous curves (Figures 1 and 2): data characterized by $\Psi_{\text {SwP }}$ lower than $-3.5 \mathrm{MPa}$, data characterized by $\Psi_{\mathrm{SWP}}$ between -3.5 and $-2 \mathrm{MPa}$ and data characterized by $\Psi_{\mathrm{SWP}}$ higher than $-2 \mathrm{MPa}$.

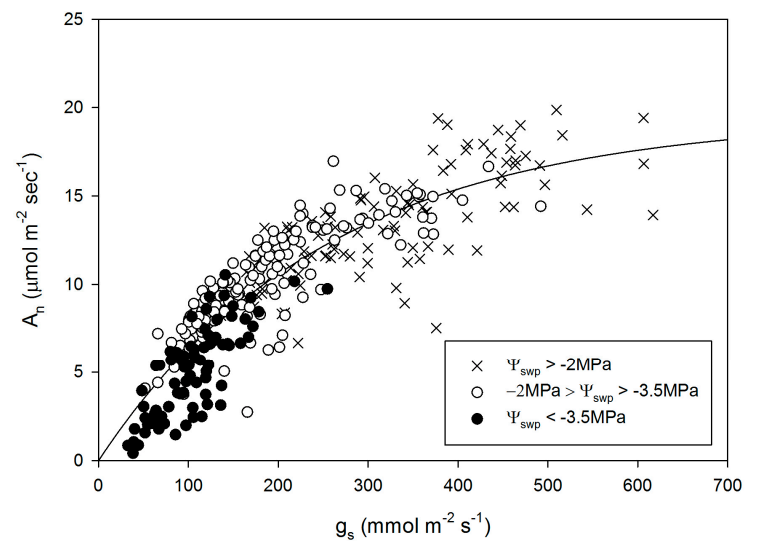

Figure 3. Relationship between net photosynthesis $\left(A_{n}, \mu m o l m^{-2} s^{-1}\right)$ and stomatal conductance $\left.\left(\mathrm{g}_{\mathrm{s}} \mathrm{mmol} \mathrm{m} \mathrm{m}^{-2} \mathrm{~s}^{-1}\right)\right)$. The best fit relationship, for the entire data pool, was obtained using an exponential function: $y=19.4 \times\left(1-\mathrm{e}^{(-0.0039 x)}\right) ; \mathrm{r}^{2}=0.80 ; p<0.0001$. 
For $\Psi_{\text {SWP }}$ below $-3.5 \mathrm{MPa}, \mathrm{g}_{\mathrm{s}}$ values were below approx. $150 \mathrm{mmol} \mathrm{m}^{-2} \mathrm{~s}^{-1}$ and the $\mathrm{A}_{\mathrm{n}}$ increased sharply and linearly from 0 to $8 \mu \mathrm{mol} \mathrm{m} \mathrm{m}^{-2} \mathrm{~s}^{-1}$ as stomata progressively opened. For $\Psi_{S W P}$ ranging from -2 to $-3.5 \mathrm{MPa}$, the relation between $g_{s}$ and $A_{n}$ was curvilinear. $A_{n}$ increased from 8 to $15 \mu \mathrm{mol} \mathrm{m}{ }^{-2} \mathrm{~s}^{-1}$ and $\mathrm{g}_{\mathrm{s}}$ from 150 to $350 \mathrm{mmol} \mathrm{m}^{-2} \mathrm{~s}^{-1}$. The points characterized by a $\Psi_{\text {SWP }}$ above $-2 \mathrm{MPa}$ were in the asymptotic part of the curve highlighting a wide variability in $\mathrm{g}_{\mathrm{s}}$ (ranging from 350 to $600 \mathrm{mmol} \mathrm{m}^{-2} \mathrm{~s}^{-1}$ ) corresponding to a low variability in $\mathrm{A}_{\mathrm{n}}$ (from 15 to $17 \mu \mathrm{mol} \mathrm{m}^{-2} \mathrm{~s}^{-1}$ ).

Intrinsic water use efficiency (iWUE) had the highest values (median of $0.06 \mathrm{mmol} \mathrm{mol}^{-1}$ ) in plants characterized by $\Psi_{\text {SWP }}$ between -3.5 and $-2 \mathrm{MPa}$. Lower iWUE values (about $0.04 \mathrm{mmol}$ $\mathrm{mol}^{-1}$ ) were observed when $\Psi_{\mathrm{SWP}}$ decreased below $-3.5 \mathrm{MPa}$ or increased above $-2 \mathrm{MPa}$ (Figure 4 ).

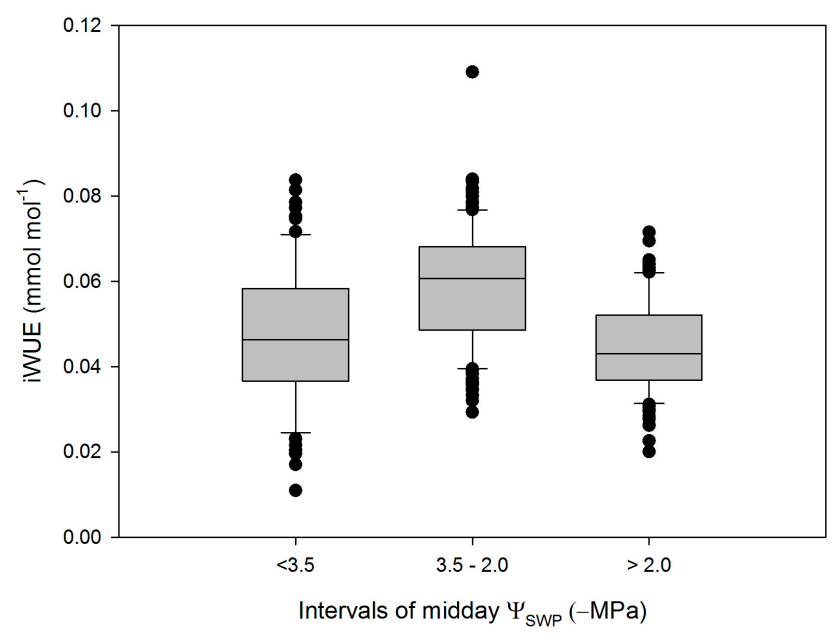

Figure 4. Intrinsic water use efficiency (iWUE, $\mathrm{mmol} \mathrm{mol}^{-1}$ ) for the selected midday stem water potential $\left(\Psi_{\mathrm{SWP}}, \mathrm{MPa}\right)$ intervals.

\section{Discussion}

The non-linear relation observed by analyzing the pooled data of $\Psi_{S W P}$ and $g_{s}$ clearly suggests that the mechanisms involved in stomatal control vary according to the stress level [42].

Multiple studies have reported on the threshold for this relationship [23,26,43]. Generally, the best fit, in accordance to our study, is positive and exponential [44-46] but also linear [23] and logistic regressions were observed [26]. The main reason for this discrepancy can be the limited variability of $\Psi_{\text {SWP values. }} \Psi_{\text {SWP }}$ data set of this experiment widely ranged, from -1 to $-7 \mathrm{MPa}$, and $\mathrm{g}_{\mathrm{s}}$ increased from 20 to more than $600 \mathrm{mmol} \mathrm{m} \mathrm{m} \mathrm{s}^{-1}$. If only the data points characterized by a $\Psi_{\mathrm{SWP}}$ above $-3.5 \mathrm{MPa}$ are used, a linear and weaker regression is observed also in this work (data not shown); if only data above $-2 \mathrm{MPa}$ are analyzed no relationship between $\Psi_{\mathrm{SWP}}$ and $\mathrm{g}_{\mathrm{s}}$ is observed.

The marked variability in $\mathrm{g}_{\mathrm{s}}$ (ranging from 600 to $250 \mathrm{mmol} \mathrm{m}^{-2} \mathrm{~s}^{-1}$ ) detected in this work for $\Psi_{\text {SWP }}$ above $-2 \mathrm{MPa}$, suggest that a $\Psi_{\text {SWP }}-\mathrm{g}_{\mathrm{s}}$ model at very low level of stress is not reliable.

Such high variability of $g_{s}$ is probably due to the superimposition of environmental factors affecting stomatal behavior in well-irrigated trees [42]. This has been previously demonstrated for olive by Moriana et al. [12], reporting vapor pressure deficit to affect the relationship between $\Psi_{\text {SWP }}$ $\operatorname{andg}_{\mathrm{s}}$ only at low to moderate stress while no effect was observed at high stress. Oscillation of stomatal conductance that occur in olive, mainly in non-stressed plants $[47,48]$, may contribute to increased variability in measured $g_{s}$ values at low to no-stress conditions.

As the stress intensified $\left(-3.5 \mathrm{MPa}<\Psi_{\mathrm{SWP}}<-2 \mathrm{MPa}\right.$ in this work), stomata progressively closed suggesting hydraulic feedback largely controls the mechanism [42]. Mildly stressed olive trees restrict excessive water loss and prevent an excessive drop in $\Psi_{\text {SWP }}$ by modulating stomatal closure [49], which is the earliest response to drought, and the major limitation to photosynthesis at mild to moderate drought [27]. 
At very high levels of stress ( $\Psi_{\text {SWP }}<-3.5 \mathrm{MPa}$ ) the small variation of both $g_{s}$ and $A_{n}$ in response to $\Psi_{\text {SWP }}$ confirm that water deficit override the effect of other parameters on olive physiology and on stomatal control of gas exchange [50].

A double exponential equation was used because allowed to better distinguish the different mechanisms involved in stomatal response to drought [42] with respect to a single exponential curve. Variation in $\mathrm{g}_{\mathrm{s}}$ affected the assimilation rate differently depending on the drought level as demonstrated by the analysis of the curve in Figure 3. This allows definition of different regions in this relationship, characterized by the different effects of drought on photosynthesis.

The first region is represented by the curvilinear and slight decrease in $A_{n}$ for $g_{s}$ decreasing from maximum values to $250 \mathrm{mmol} \mathrm{m} \mathrm{m}^{-2} \mathrm{~s}^{-1}$. Very high maximum values of $g_{\mathrm{s}}$ were observed reaching up to $600 \mathrm{mmol} \mathrm{m}^{-2} \mathrm{~s}^{-1}$. These values are higher then what reported by different authors [31,51,52]. However, similarly to what reported by Fernandez et al. [32], the increase in transpiration did not correspond to an increase in $A_{n}$ that showed maximum value of $20 \mu \mathrm{mol} \mathrm{m}^{-2} \mathrm{~s}^{-1}$.

In this range of values, a decrease in $\mathrm{g}_{\mathrm{s}}$ corresponded to a parallel decline in the sub-stomatal $\mathrm{CO}_{2}$ concentration (Figure 2), which directly affected the photosynthetic rate.

Considering that plants were characterized by $\Psi_{\text {SWP }}$ values above $-3.5 \mathrm{MPa}$, this suggested that at low to mild stress levels, stomatal limitations to photosynthesis were dominant. At this level of stress, consistent with earlier reports [49,53,54], progressive drought increased iWUE (Figures 2B and 4).

Non-stomatal factors were predominant at higher levels of stress. For example, as $\Psi_{S W P}$ dropped to $-3.5 \mathrm{MPa}$ and $\mathrm{g}_{\mathrm{s}}$ dropped below $150 \mathrm{mmol} \mathrm{m}^{-2} \mathrm{~s}^{-1}, \mathrm{C}_{\mathrm{i}}$ increased proportionally (Figure 3), reflecting the impaired photosynthetic metabolism in these plants, and, consequentially, iWUE decreased (Figures 2A and 4). For instance, a steeper slope of the function $A_{n}$ for $g_{s}$, observed for values lower than $150 \mathrm{mmol} \mathrm{m}^{-2} \mathrm{~s}^{-1}$, reflects the superimposition of non-stomatal factors affecting photosynthesis (Figure 2). Other authors found a similar pattern with $C_{i}$, initially declining with increasing stress and then increasing as drought stress became more severe [55]. Other studies confirm the possibility of using $C_{i}$ as an indicator of the stomatal or non-stomatal limitations to photosynthesis $[27,56,57]$. In an experiment conducted on nine different conifer species, Brodribb [58] observed that a rapid increase in $C_{i}$ values at certain levels of water stress was accompanied by a rapid loss of fluorescence from PSII, suggesting damage to the photosynthetic apparatus of plants under drought beyond the minimum $C_{i}$, also called the $C_{i}$ inflexion point by Flexas et al. [20]. Finally, analysis with data from literature, using $\mathrm{g}_{\mathrm{s}}$ as a reference $[19,25]$, demonstrated that the point at which $C_{i}$ starts to increase is accompanied by a steep reduction in the net photosynthetic rate $\left(\mathrm{A}_{\mathrm{n}}\right.$, reduced by $\left.70 \%\right)$, in the $\mathrm{CO}_{2}$-saturated rate of photosynthesis $\left(\mathrm{A}_{\text {sat }}\right.$, reduced by $50 \%$ ), in the apparent carboxylation efficiency $(\varepsilon$, reduced by $50 \%$ ) and in the rate of light-saturated electron transport (ETR, reduced by $40 \%$ ).

\section{Conclusions}

The results of this experiment provide physiological data to support the plant based irrigation schedule of an olive orchard designed to increase water use efficiency.

Based on the effects of drought stress on the principal ecophysiological parameters, we were able to define three different levels of stress represented by thresholds in $\Psi_{\text {SWP }}$ values. The first, $\Psi_{\text {SWP }}$ above about $-2.0 \mathrm{MPa}$, is characterized by the absence of stress. In this state, a wide variation in stomatal conductance is observed unrelated to $\Psi_{\mathrm{SWP}}$ variation.

Superimposition of environmental and plant or site specific factors affects stomatal behavior in well-irrigated trees.

Increased $g_{s}$ in this state was not clearly improving leave assimilation rates and, as a consequence, resulted in reduced iWUE.

Moderate stress was described by a $\Psi_{\text {SWP }}$ between about -2 and $-3.5 \mathrm{MPa}$, and was characterized by stomatal regulation of gas exchange. A reduction in water volume remaining in this range of potential improved iWUE, determining water savings. On the basis of the study conducted by Marra et al. [7], this stress level benefits oil quality without affecting system productivity. Finally, 
below about $-3.5 \mathrm{MPa}$, non-stomatal limits to photosynthesis are predominant. This represents a threshold value for high stress levels, which should be avoided because it is dangerous to the plant and has a marked and negative effect on both gas exchange and productivity.

Author Contributions: G.M. performed the experiments, analyzed data and wrote the paper. T.C. conceived and designed the experiments and revised the manuscript. L.F. edited the English and revised the manuscript. F.P.M. conceived and designed the experiment, analyzed data and revised the manuscript.

Conflicts of Interest: The authors declare no conflict of interest.

\section{References}

1. Camposeo, S.; Godini, A. Preliminary observations about the performance of 13 varieties according to the super high density oliveculture training system in Apulia (southern Italy). Adv. Hortic. Sci. 2010, 24, 16-20.

2. Tous, J.; Romero, A.; Plana, J.; Hermoso, J.F. Olive oil cultivars suitable for very high density planting conditions. Acta Hortic. 2008, 791, 403-408. [CrossRef]

3. Tous, J.; Romero, A.; Hermoso, J.F. New trends in olive orchard design for continuous mechanical harvesting. Adv. Hortic. Sci. 2010, 24, 43-52.

4. Pastor, M.; García-Vila, M.; Soriano, M.A.; Vega, V.; Fereres, E. Productivity of olive orchards in response to tree density. J. Hortic. Sci. Biotechnol. 2007, 82, 555-562. [CrossRef]

5. Policarpo, M.; Talluto, G.; Lo Bianco, R. Vegetative and productive responses of 'Conference' and 'Williams' pear trees planted at different in-row spacing. Sci. Hortic. 2006, 109, 322-331. [CrossRef]

6. Marino, G.; Pernice, F.; Marra, F.P.; Caruso, T. Validation of an online system for the continuous monitoring of tree water status for sustainable irrigation managements in olive (Olea europaea L.). Agric. Water Manag. 2016, 177, 298-307. [CrossRef]

7. Marra, P.F.; Marino, G.; Marchese, A.; Caruso, T. Effects of different irrigation regimes on a super-high density olive grove cv. 'Arbequina', vegetative growth, productivity and polyphenol content of the oil. Irrig. Sci. 2016, 34, 1-13. [CrossRef]

8. Grattan, S.R.; Berenguer, M.J.; Connell, J.H.; Polito, V.S.; Vossen, P.M. Olive oil production as influenced by different quantities of applied water. Agric. Water Manag. 2006, 85, 133-140. [CrossRef]

9. Gómez-del-Campo, M. Summer deficit-irrigation strategies in a hedgerow olive orchard cv. 'Arbequina': Effect on fruit characteristics and yield. Irrig. Sci. 2013, 31, 259-269. [CrossRef]

10. Turner, N.C. Plant water relations and irrigation management. Agric. Water Manag. 1990, 17, 59-73. [CrossRef]

11. Fereres, E.; Goldhamer, D. Deciduous fruit and nut trees. In Irrigation of Agricultural Crops. Agronomy Monograph No. 30; Stewart, B.A., Nielsen, D.R., Eds.; American Society of Agronomy: Madison, WI, USA, 1990; pp. 987-1017.

12. Moriana, A.; Pérez-López, D.; Prieto, M.H.; Ramírez-Santa-Pau, M.; Pérez-Rodriguez, J.M. Midday stem water potential as a useful tool for estimating irrigation requirements in olive trees. Agric. Water Manag. 2012, 112, 43-54. [CrossRef]

13. Gómez-del-Campo, M.; Leal, A.; Pezuela, C. Relationship of stem water potential and leaf conductance to vegetative growth of young olive trees in a hedgerow orchard. Aust. J. Agric. Res. 2008, 59, 270-279. [CrossRef]

14. Gómez-del-Campo, M. Physiological and growth responses to irrigation of a newly established hedgerow Olive orchard. HortScience 2010, 45, 809-814.

15. Gómez-del-Campo, M. Summer deficit irrigation in a hedgerow olive orchard cv. Arbequina: Relationship between soil and tree water status, and growth and yield components. Span. J. Agric. Res. 2013, 11, 547-557. [CrossRef]

16. Corell, M.; Pérez-López, D.; Martín-Palomo, M.J.; Centeno, A.; Girón, I.; Galindo, A.; Moreno, F. Comparison of the water potential baseline in different locations. Usefulness for irrigation scheduling of olive orchards. Agric. Water Manag. 2016, 177, 308-316. [CrossRef]

17. Di Vaio, C.; Marallo, N.; Marino, G.; Caruso, T. Effect of water stress on dry matter accumulation and partitioning in pot-grown olive trees (cv. Leccino and Racioppella). Sci. Hortic. 2013, 164, 155-159. [CrossRef] 
18. Flexas, J.; Bota, J.; Cifre, J.; Mariano, E.J.; Galmés, J.; Gulías, J.; Lefi, E.-K.; Martínez-Cañellas, S.F.; Moreno, M.T.; Ribas-Carbó, M.; et al. Understanding down-regulation of photosynthesis under water stress: Future prospects and searching for physiological tools for irrigation management. Ann. Appl. Biol. 2004, 144, 273-283. [CrossRef]

19. Medrano, H.; Escalona, J.M.; Bota, J.; Gulías, J.; Flexas, J. Regulation of photosynthesis of C3 plants in response to progressive drought: The interest of stomatal conductance as a reference parameter. Ann. Bot. 2002, 89, 895-905. [CrossRef] [PubMed]

20. Flexas, J.; Bota, J.; Escalona, J.M.; Sampol, B.; Medrano, H. Effects of drought on photosynthesis in grapevines under field conditions: An evaluation of stomatal and mesophyll limitations. Funct. Plant Biol. 2002, 29, 461-471. [CrossRef]

21. Flexas, J.; Escalona, J.M.; Evain, S.; Gulİas, J.; Moya, I.; Osmond, C.B.; Medrano, H. Steady-state chlorophyll fluorescence (Fs) measurements as a tool to follow variations of net $\mathrm{CO}_{2}$ assimilation and stomatal conductance during water-stress in C3 plants. Physiol. Plant. 2002, 114, 231-240. [CrossRef] [PubMed]

22. Fernández, J.E.; Moreno, F.; Girón, I.F.; Blázquez, O.M. Stomatal control of water use in olive tree leaves. Plant Soil 1997, 190, 179-192. [CrossRef]

23. Giorio, P.; Sorrentino, G.; d'Andria, R. Stomatal behaviour, leaf water status and photosynthetic response in fieldgrown olive trees under water deficit. Environ. Exp. Bot. 1999, 42, 95-104. [CrossRef]

24. Bongi, G.; Palliotti, A. Olive. In Handbook of Environmental Physiology of Fruit Crops; Temperate Crops Volume I; Shaffer, B., Anderson, P.C., Eds.; CRC Press: Boca Raton, FL, USA, 1994; pp. 165-187.

25. Angelopoulos, K.; Dichio, B.; Xiloyannis, C. Inhibition of photosynthesis in olive trees (Olea europaea L.) during water stress and rewatering. J. Exp. Bot. 1996, 47, 1093-1100. [CrossRef]

26. Di Vaio, C.; Marra, F.P.; Scaglione, G.; La Mantia, M.; Caruso, T. The effect of different vigour olive clones on growth, dry matter partitioning and gas exchange under water deficit. Sci. Hortic. 2012, 134, 72-78. [CrossRef]

27. Flexas, J.; Medrano, H. Drought-inhibition of photosynthesis in C3 plants: Stomatal and non-stomatal limitation revisited. Ann. Bot. 2002, 89, 183-189. [CrossRef] [PubMed]

28. Jones, H.G. Partitioning stomatal and non-stomatal limitations to photosynthesis. Plant Cell Environ. 1985, 8, 95-104. [CrossRef]

29. Düring, $\mathrm{H} . \mathrm{CO}_{2}$ assimilation and photorespiration of grapevine leaves: Responses to light and drought. Vitis 1988, 27, 199-208.

30. Quick, W.P.; Chaves, M.M.; Wendler, R.; David, M.; Rodrigues, M.L.; Passaharinho, J.A.; Pereira, J.S.; Adcock, M.D.; Leegood, R.C.; Stitt, M. The effect of water stress on photosynthetic carbon metabolism in four species grown under field conditions. Plant Cell Environ. 1992, 15, 25-35. [CrossRef]

31. Fernández, J.E.; Diaz-Espejo, A.; D'Andria, R.; Sebastiani, L.; Tognetti, R. Potential and limitations of improving olive orchard design and management through modelling. Plant Biosyst. 2008, 142, 130-137. [CrossRef]

32. Allen, R.G.; Pereira, L.S.; Raes, D.; Smith, M. Crop evapotranspiration. In Guidelines for Computing Crop Water Requirements; Irrigation and Drainage Paper 56; FAO: Rome, Italy, 1998.

33. Fernández, J.E.; Díaz-Espejo, A.; Infante, J.M.; Durán, P.; Palomo, M.J.; Chamorro, V.; Girón, I.F.; Villagarcía, L. Water relations and gas exchange in olive trees under regulated deficit irrigation and partial rootzone drying. Plant Soil 2006, 284, 273-291. [CrossRef]

34. Orgaz, F.; Villalobos, F.; Testi, L.; Pastor, M.; Hidalgo, J.C.; Fereres, E. Programación de riegos en plantaciones de olivar. Metodología para el cálculo de las necesidades de agua de riego en el olivar regado por goteo. In Cultivo Del Olivo Con Riego Localizado; Pastor, M., Ed.; Mundi-Prensa: Madrid, Spain, 2005; pp. 83-138.

35. Orgaz, F.; Fereres, E.; Riego, D.B. El Cultivo Del Olivo; Barranco, D., Fernández-Escobar, R., Rallo, L., Eds.; Mundi-Prensa: Madrid, Spain, 1997; pp. 251-272.

36. Testi, L.; Villalobos, F.J.; Orgaz, F. Evapotranspiration of a young irrigated olive orchard in southern Spain. Agric. Meteorol. 2004, 121,1-18. [CrossRef]

37. Fernández, J.E. Understanding olive adaptation to abiotic stresses as a tool to increase crop performance. Env. Exp. Bot. 2014, 103, 158-179. [CrossRef]

38. Marino, G.; Macaluso, L.; Marra, F.P.; Ferguson, L.; Marchese, A.; Campisi, G.; Volo, P.; Laudicina, V.A.; Caruso, T. Horticultural performance of 23 Sicilian olive genotypes in hedgerow systems: Vegetative growth, productive potential and oil quality. Sci. Hortic. 2017, 217, 217-225. [CrossRef] 
39. Begg, J.E.; Turner, N.C. Water potential gradients in field tobacco. Plant Physiol. 1970, 46, 343-346. [CrossRef] [PubMed]

40. Parkinson, K.J. Porometry in SEB. In Symposium of Instrumentation for Environmental Physiology; Cambridge University Press: Cambridge, UK, 1983.

41. Parkinson, K.J.; Day, W.; Leach, J.E. A portable system for measuring the photosynthesis and transpiration of graminaceous leaves. J. Exp. Bot. 1980, 31, 1441-1453. [CrossRef]

42. Jones, H.G. Stomatal control of photosynthesis and transpiration. J. Exp. Bot. 1998, 49, 387-398. [CrossRef]

43. Fernández, J.E.; Moreno, F.; Martín-Aranda, J. Water status of olive trees under dry-farming and drip-irrigation. Acta Hortic. 1993, 335, 157-164. [CrossRef]

44. Erel, R.; Ben-Gal, A.; Dag, A.; Schwartz, A.; Yermiyahu, U. Sodium replacement of potassium in physiological processes of olive trees (var. Barnea) as affected by drought. Tree Physiol. 2014, 34, 1102-1117. [CrossRef] [PubMed]

45. Fernandes, R.D.M.; Cuevas, M.V.; Hernandez-Santana, V.; Rodriguez-Dominguez, C.M.; Padilla-Díaz, C.M.; Fernández, J.E. Classification models for automatic identification of daily states from leaf turgor related measurements in olive. Comput. Electron. Agric. 2017, 142, 181-189. [CrossRef]

46. Naor, A.; Schneider, D.; Ben-Gal, A.; Zipori, I.; Dag, A.; Kerem, Z.; Birger, R.; Peres, M.; Gal, Y. The effects of crop load and irrigation rate in the oil accumulation stage on oil yield and water relations of 'Koroneiki' olives. Irrig. Sci. 2013, 31, 781-791. [CrossRef]

47. López-Bernal, A.; García-Tejera, O.; Testi, L.; Orgaz, F.; Villalobos, F.J. Stomatal oscillations in olive trees: Analysis and methodological implications. Tree Physiol. 2017, 1-12. [CrossRef] [PubMed]

48. Fernández, J.E.; Rodriguez-Dominguez, C.M.; Perez-Martin, A.; Zimmermann, U.; Rüger, S.; Martín-Palomo, M.J.; Torres-Ruiz, J.M.; Cuevas, M.V.; Sann, C.; Ehren-berger, W.; et al. Online-monitoring of tree water stress in a hedgerow olive orchard using the leaf patch clamp pressure probe. Agric. Water Manag. 2011, 100, 25-35. [CrossRef]

49. Tognetti, R.; d'Andria, R.; Lavini, A.; Morelli, G. The effect of deficit irrigation on crop yield and vegetative development of Olea europaea L. (cvs. Frantoio and Leccino). Eur. J. Agron. 2006, 25, 356-364. [CrossRef]

50. Moriana, A.; Villalobos, F.J.; Fereres, E. Stomatal and photosynthetic responses of olive (Olea europaea L.) leaves to water deficits. Plant Cell Environ. 2002, 25, 395-405. [CrossRef]

51. Diaz-Espejo, A.; Walcroft, A.S.; Fernandez, J.E.; Hafidi, B.; Palomo, M.J.; Giron, I.F. Modeling photosynthesis in olive leaves under drought conditions. Tree Physiol. 2006, 26, 1445-1456. [CrossRef] [PubMed]

52. Cuevas, M.V.; Torres-Ruiz, J.M.; Álvarez, R.; Jiménez, M.D.; Cuerva, J.; Fernández, J.E. Assessment of trunk diameter variation derived indices as waterstress indicators in mature olive trees. Agron. Water Manag. 2010, 97, 1293-1302. [CrossRef]

53. Chartzoulakis, K.; Michelakis, N.; Tzombanakis, I. Effect of water amount and application date on yield and water utilisation efficiency of 'Koroneiki' olives under drip irrigation. Adv. Hortic. Sci. 1992, 2, 82-84.

54. Wahbi, S.; Wakrim, R.; Aganchich, B.; Serraj, R. Effects of partial rootzone drying (PRD) on adult olive tree (Olea europaea) in field conditions under arid climate. I. Physiological and agronomic responses. Agric. Ecosyst. Environ. 2005, 106, 289-301. [CrossRef]

55. Lawlor, D.W. The effects of water deficit on photosynthesis. In Environment and Plant Metabolism: Flexibility and Acclimation; Smirnoff, N., Ed.; BIOS Scientific Publishers: Oxford, UK, 1995; pp. 129-160.

56. Cornic, G.; Massacci, A. Leaf photosynthesis under drought stress. In Advances in Photosynthesis: Photosynthesis and the Environment Volume 5; Baker, N.R., Ed.; Kluwer Academic Publishers: Dordrecht, The Netherlands, 1996; pp. 347-366.

57. Ort, D.R.; Oxborough, K.; Wise, R.R. Depressions of photosynthesis in crops with water deficits, In Photoinhibition of Photosynthesis: From Molecular Mechanisms to the Field; Baker, N.R., Bowyer, J.R., Eds.; BIOS Scientific Publishers: Oxford, UK, 1994; pp. 315-329.

58. Brodribb, T. Dynamics of changing intercellular $\mathrm{CO}_{2}$ concentration (ci) during drought and determination of minimum functional ci. Plant Physiol. 1996, 111, 179-185. [CrossRef] [PubMed]

(C) 2018 by the authors. Licensee MDPI, Basel, Switzerland. This article is an open access article distributed under the terms and conditions of the Creative Commons Attribution (CC BY) license (http:/ / creativecommons.org/licenses/by/4.0/). 